\title{
The supplementation of Fermented Feed (Indegofera $S p$ and Eurycoma longifolia) Leaves on Arabic Chicken Semen
}

\author{
Mustaqim mustaqim*, Zulkifli zulkifli, Cut Rauzatul Jannah, Salsabila \\ Department of Animal Husbandry, Faculty of Agricultural and Animal Sciences, \\ University of Islam Kebangsaan Indonesia. Aceh \\ *Corresponding author. E-mail: mustaqimt48@gmail.com
}

\begin{abstract}
This study aims to determine the effect offermented feed in the form of Indegofera Sp. and Eurycoma longifolia (El) leaves on the quality of Arabian chicken semen. This study used a completely randomized design (CRD) with 4 treatments and 3 replications. The treatments consisted of P. 1 : Commercial Feed, P. $2: 80 \%$ Indegofera $s p+20 \%$ Eurycoma longifolia (El) leaves, P.3: $70 \%$ Indegofera sp leaves $+30 \%$ Eurycoma longifolia (El) leaves, P.4 : 60\% Indegofera sp + 40\% Eurycoma longifolia (El) leaves. Semen collection was carried out on day 30 after feeding. The semen quality were observed and analyzed using one-way analysis of variance (ANOVA). The results showed that the combination of two fermented feed (Indegofera Sp and Eurycoma Longifolia) leaves had a significant effect (P\&lt;0.05) on the quality of arab chicken spermatozoa. The fermented feed is able to improve the quality of Arabic chicken semen.
\end{abstract}

Keywords: Arabic chicken, fermented feed, semen quality

\section{Introduction}

Arabic chicken is one of laying hens with high selling value in the market and is potential to be developed. The egg quality of Arabic chickens is almost the same as the quality of native chicken eggs, both in terms of size, color, and nutritional content. [1] said that Arabic chicken as well as their eggs are popular in the community and have a high demand. Thus, semen freezing is needed to be applied in order to maintain Arabic chicken stock. Semen freezing is one of the technologies becoming a breakthrough in the conservation of semen for native Indonesian chickens [2]. However, Arab chicken breeding in Aceh is still carried out naturally by providing feed and letting them mate by themselves. Thus, the stock for commercial and research purposes is still limited.

Artificial insemination (AI) technology has been carried out on several animals such as cows, goats, and fish. The AI application is an alternative in solving problems regarding the procurement of seeds in a short time, and can also be used to multiply superior seeds as well as for research purposes[3]. However, the AI method is unfamiliar to small farmers, especially in Aceh. In facts, AI method can increase the efficiency of males used, save costs and maintenance, prevent disease transmission, and increase reproductive efficiency. [4] stated that even though AI method is effective in breeding, there are many people lacks of skill on how to do it. In his research, [5] states that good quality semen can be determined from the type of feed given. [6] states that good semen quality can be obtained by giving nutritious feed.

Two plants commonly used as animal feed are Indegofera sp and Eurycoma longifolia (El). Indegofera $s p$ has been known to have potential as a source of high quality feed. These plants are widely known in Java and other areas. However, the farmer in Aceh is unfamiliar with these plants. [7] stated that Indigofera sp is very potential as animal feed, because of its biomass production and high protein content. Eurycoma longifolia $(\mathrm{El})$ has been long used as traditional medicine, especially 
for people living in Southeast Asia. Eurycoma longifolia (El) has a bladder that actively increase sperm quality. [8] said that superior males are a supporting factor to get good quality semen. [9] stated, Eurycoma longifolia (El) is used to restore energy and body vitality, increase blood flow and health in animals.

One of appropriate technology to be applied to increase feed quality is to add probiotic fermented feed. Probiotic fermented feed is feed that has high nutritional value because of microbial fermentation. Probiotic microbes decomposes undigested organic components to increase digestibility in animal digestive system[10]. [11] Said that the fermented feed contains higher protein value than the ordinary commercial feed. Based on high protein content in fermented feed, it is necessary to conduct research to determine whether there is a better effect on increasing the quality of Arabic chicken semen given fermented Indegofera sp and Eurycoma longifolia (El) leaves as alternative feed ingredients.

\section{Material and Methods}

\section{Time and place}

This research was carried out from July to August 2021 in Cage Land of SMK Negeri 1 Ganda Pura, Bireuen Regency, Aceh Province

\section{Experimental design}

The method used in this study was a completely randomized design (CRD) with 4 treatments and 3 replications The treatments consisted of P.1 : Commercial Feed, P.2: 80\% Indegofera sp + 20\% Eurycoma longifolia (El) leaves, P.3: 70\% Indegofera sp leaves $+30 \%$ Eurycoma longifolia (El) leaves, P.4: 60\% Indegofera sp leaves $+40 \%$ Eurycoma longifolia $(\mathrm{El})$ leaves. The chicken was feed 3 times a day.

\section{Procedures}

\section{Preparation of chicken coop}

The roosters used in this study were $12-15$ months old. The size of coop was $80 \times 80 \times 80 \mathrm{~cm}$ with a total of 12 chicken coops. The coops were made of bamboo and wood.

\section{Preparation of test feed}

The fresh leaves were chopped to a size of $2-3 \mathrm{~cm}$, then dried on a plastic sheeting with sunlight for 6 hours. The leaves of Indegofera sp and Eurycoma longifolia (El) were fermented using yeast (in aerobic condition), then put in a large plastic bag and then tied. After 7 days, the fermented products are dismantled and then dried. After drying, the products were grinded with a flour milling machine to make flour. The feeding frequency was 3 times a day at $07.00 \mathrm{WIB}, 12.00 \mathrm{WIB}$, and 17.00 WIB.

\section{Semen collection}

Semen was collected by applying sequencing method on the dorsal back of the rooster using an ejaculatory machine[12]. Semen collection was carried out on day 30 after feeding, so that the feed given can affect the quality of the sperm produced. Before starting the collection, the back of the chickens around the lip and bottom of the cloaca were cleaned with tissue paper that had been moistened with physiological $\mathrm{NaCl}$. The massage method uses the fingers of the right hand to rub the back to the base of the tail, then continues up to the tail. The right hand grasps and slightly lifts the base of the tail [13]. 


\section{Parameter}

1. Motility

Spermatozoa motility is the movement of spermatozoa which is measured using an object glass under microscope with a magnification of $400 \mathrm{x}$ [14].

\section{Viability}

Spermatozoa viability is one of the indicators to determine the quality of semen. The viability of fresh poultry semen at room temperature can last for 30 minutes since ejaculation. the percentage of live and dead sperm was calculated using eosin. Eosin (red color) was used as a dye for live spermatozoa, while negrosin (blue color) served as the background [14].

\section{Abnormalities}

Spermatozoa abnormalities are distinguished between primary and secondary forms of abnormality, primary abnormality caused by testes disorders while secondary abnormalities caused by treatment errors after semen is removed from the testes (due to harsh shaking, fast drying, high temperature, and errors in making smear preparations) [14]

\section{Results and Discussion}

\section{Semen Quality}

The examination result of the semen of Arabian chickens fed with fermented leaves of Indegofera sp and Eurycoma longifolia (el) is provided in Table 1. The results of macroscopic and microscopic examination of Arabian chicken semen are as follows:

Table 1.

Quality of Arabian chicken semen

\begin{tabular}{|c|c|c|c|c|}
\hline \multirow{2}{*}{ Parameter } & \multicolumn{4}{|c|}{ Treatments } \\
\hline & P1 & P2 & P3 & P4 \\
\hline \multicolumn{5}{|l|}{ Macroscopic } \\
\hline Color & Cream & Cream & Cream & Cream \\
\hline Consistency & Thick & Thick & Thick & Thick \\
\hline $\mathrm{pH}$ & $7,10 \pm 0,13^{\mathrm{a}}$ & $7,20 \pm 0,16^{\mathrm{b}}$ & $7,25 \pm 0,10^{\mathrm{b}}$ & $7,25 \pm 0,17^{\mathrm{b}}$ \\
\hline Volume (ml) & $0,17 \pm 0,03^{\mathrm{a}}$ & $0,20 \pm 0,04^{b}$ & $0,25 \pm 0,04^{\mathrm{b}}$ & $0,27 \pm 0,04^{\mathrm{b}}$ \\
\hline \multicolumn{5}{|l|}{ Microscopic } \\
\hline $\begin{array}{l}\text { Semen concenteration }(\mathrm{x} \\
\left.10^{9} / \mathrm{ml}\right)\end{array}$ & $2,08 \pm 0,15^{\mathrm{a}}$ & $2,51 \pm 0,36^{\mathrm{b}}$ & $2,68 \pm 0,29^{\mathrm{b}}$ & $2,82 \pm 0,28^{b}$ \\
\hline Motility (\%) & $76,00 \pm 4,18^{\mathrm{a}}$ & $80,40 \pm 2,88^{\mathrm{b}}$ & $83,60 \pm 2,51^{\mathrm{c}}$ & $84,00 \pm 2,24^{\mathrm{c}}$ \\
\hline Viability (\%) & $81,80 \pm 3,77^{\mathrm{a}}$ & $84,60 \pm 3,21^{\mathrm{ab}}$ & $86,60 \pm 2,70^{\mathrm{b}}$ & $87,20 \pm 2,17^{b}$ \\
\hline Abnormality (\%) & $5,40 \pm 1,52^{\mathrm{a}}$ & $4,60 \pm 1,14^{\mathrm{a}}$ & $4,40 \pm 1,52^{\mathrm{a}}$ & $4,20 \pm 0,84^{\mathrm{a}}$ \\
\hline
\end{tabular}

The color of semen in this study was cream with thick consistency. This is in line with [15] that stated the color and consistency of normal Arab chicken sperm for fertilization are cream in color and thick in consistency. [16] Also mentioned that in general, semen with good quality characterized by its cream color and thick consistency. Semen color is an indicator of spermatozoa density in one ejaculation [17].

The degree of acidity can affect the viability of spermatozoa. If the $\mathrm{pH}$ is too high/low, it will cause spermatozoa to die. $\mathrm{pH}$ in semen in all treatments ranged from 7.10 to 7.25 which classified 
as normal. [15] Said that the degree of acidity (pH) of cement generally ranges from 7.0 to 7.6. [18] in his study also stated that the acidity of cement in general was in the neutral $\mathrm{pH}$ range. High and low $\mathrm{pH}$ also related to the concentration of spermatozoa [19]. This is in accordance with the opinion of [16], increasing sperm concentration can affect the $\mathrm{pH}$ of semen

The volume of semen and the concentration of spermatozoa describe the ability of males to mate the female chickens as long as the mating is carried out using the AI technique. Semen volume is one of the first steps to assess the productivity of males [20]. The average volume of semen produced during the study was $0.17-0.27 \mathrm{ml}$ and is eligible for IB. This is in accordance with [21] that the optimal volume of chicken semen for AI ranged from $0.3-1.5 \mathrm{ml}$. In another study, [22] mentioned that the volume of local chicken semen ranged between 0.2 to $0.5 \mathrm{ml}$.

The concentration of semen is one indicator of semen quality to determine the number of females to be included in artificial insemination. Semen concentration in this study was $2.08-2.82$ million cells $/ \mathrm{ml}$. Semen concentration is affected by several factors, one of which is feed and libido. It is known that one of the feed Ingredients from Eurycoma longifolia (El) leaves used in this study can improve sperm quality. Eurycoma longifolia $(\mathrm{El})$ is a plant that has a bladder to increase sperm quality [23]. [24] stated that the concentration of chicken spermatozoa ranged from 0.03-11 billion cells $/ \mathrm{ml}$

Motility is the movement of sperm to measure the ability of sperm to fertilize eggs. This forward motion is very necessary especially when moving in the female genital tract to reach the site of fertilization. Based on the results of Fresh semen evaluation, Arab chicken semen in this study had good motility ranging from $76.00 \%-84.00 \%$. However, the best mortality was found in the P.4 $(84 \%)$ treatment: $60 \%$ Indegofera sp leaves $+40 \%$ Eurycoma longifolia $(\mathrm{El})$ leaves. This number is within the standard of chicken motality for artificial insemination (AI). The same result also reported by [21] that chicken semen motility of AI ranged 71-84\%. [22] reported that the quality of local chicken semen has an average motility of 60 to $80 \%$.

The viability of Arabic chicken semen that were colored using eosin was $81.80 \%-87.20 \%$ .The best viability was found in treatment P.4: $60 \%$ Indegofera sp leaves. $+40 \%$ of Eurycoma longifolia (El) leaves. This high percentage indicates that the leaves fermentation is able to improve the viability of Arabian chicken semen. [25] Stated that Indigofera sp is one of the forages which high nutritional content. Protein and energy are one of the nutrients needed by sperm during dilution process. Eurycoma longifolia (El) can increase sex drive in men, because of its active ingredients in the form of various minerals ( $\mathrm{Fe}, \mathrm{Co}, \mathrm{Mg}, \mathrm{Zn}$ ), saponins, sterols, and isoprenoids. Isoprenoids and sterols are needed for the synthesis of steroid hormones, one of which is testosterone [26].

The highest abnormality of Arab chicken semen (5.40) was found in treatment P.1 (Commercial Feed). The low quality of semen could be caused by the feed. Protein in commercial feed might not sufficient for sperm needs. [13] Reported that commercial feed is still low in protein needed for semen. In treatment P.4 (60\% Indegofera sp + 40\% Eurycoma longifolia (El) leaves), the abnormality was 4.20 , a slight better than P1 because this feed is considered to meet protein needs by spermatozoa. Abnormality is affected by pathological disorders, feed, and extreme changes in temperature and incompetence of implementers [27].

\section{Conclusion}

Based on the results of the research, it can be concluded that the addition of fermented feed made from Indegofera sp and Eurycoma longifolia (El) leaves can improve the quality of Arabic chicken semen.

\section{Acknowledgments}

This work is supported by Ministry of Education and Culture who has funded this research. We also acknowledge the support received from Indonesian National Islamic University and XIII dictation area. 
[1] Alwi. W, Agustina.L, Mide. M.Z. 2019. Performa Ayam Arab dengan Pemberian Energi-Protein pada Level Berbeda. Performa Ayam Arab dengan Pemberian Energi-Protein pada Level Berbeda. Jurnal Sains dan Teknologi Peternakan. Vol. 1(1). | E-ISSN: 2716-0424

[2] Khaeruddin. 2020. Pembekuan Spermatozoa Ayam Kampung Dengan Suplementasi Bovine Serum Albumin Dan Putih Telur Dalam Pengencer Ringer Laktat Kuning Telur. Journal of Tropical Animal Production. Vol 21, No. 2 pp. 111-222.

[3] Layek, S. S., Mohanty, T. K., Kumaresan, A. \& Parks, J. E. 2016. Cryopreservation of Bull Semen: Evolution from Egg Yolk Based To Soybean Based Extenders. Animal Reproduction Science.172, 19.

[4] Dwitya. Y, Eriani. K, Saputra. H, Azhar. Al, Rizal. M. 2019. Cryopreservation of Aceh Cattle Semen with Date (Phoenix dactylifera) Extract Supplementation. Journal of Biology \& Biology Education. Vol. 11. No.1. 117-124.

[5] Herdis. 2012. Pengaruh Waktu Penampungan Semen Terhadap Gerakan Massa Spermatozoa da Tingkah Laku Kopulasi Penjantan Domba Garut. Jurnal Sain da Teknologi Indonesia. Vol. 14. No.1. 38-43.

[6] Rahmi, Eriani. K, Dasrul. 2015. Kualitas Dan Morfologi Abnormal Spermatozoa Sapi Aceh Pada Berbagai Frekuensi Ejakulasi. Prosiding Seminar Nasional Bioti. ISBN: 978-602-18962-5-9

[7] Yuza, Al.I, Rastina, Harris. A, Ferasyi. T.R, Azhar. Al, Akmal. M. 2018. The Effect of Indigofera sp. Leaf on the Protein Level of Rabbit Meat (Orictolagus sp). Jurnal Medika Veterinaria. Vol.12 (2).97 -102 .

[8] Setiadi, D.R., H. Hasibuan, R. Indriastuti, dan A.A. Arif. 2019. Karateristik ayam IPB D-1. BOGOR: Fakultas Kedokteran Hewan, Institut Pertanian Bogor.

[9] Silalahi, Marina .2019. Hubungan Pemanfaatan Tumbuhan Pasak Bumi (Eurycoma Longifolia Jack) Sebagai Obat Tradisional Dan Bioaktivitasnya. Jurnal Pendidikan Matematika Dan Ipa.Vol. 10 (2). Pp. 109-121. ISSN 25797530.

[10] Hadid, S.M., 2015. Pengaruh umur pemotongan terhadap kualitas kimia daging ayam lokal pedaging unggul dengan pemberian pakan fermentasi. Thesis Pascasarjana Kesmavet Universitas Syiah Kuala, Banda Aceh

[11] Marhamah. S.U, Akbarillah .T, Hidayat. 2019. Kualitas Nutrisi Pakan Konsentrat Fermentasi Berbasis Bahan Limbah Ampas Tahu dan Ampas Kelapa dengan Komposisi yang Berbeda serta Tingkat Akseptabilitas pada Ternak Kambing. Jurnal Sain Peternakan Indonesia. Vol. 14. No. 2. E-ISSN2528-7109.

[12] Iswati, Isnaini. N, Susilawati. T. 2017. Fertilitas Spermatozoa Ayam Buras dengan Penambahan Antioksidan Glutathione dalam Pengencer Ringer's Selama Simpan Dingin. Jurnal Ilmu-ilmu Peternakan. Vol.27. No.1: 107 - 115

[13] Mustafa. M, Dasrul. D, Yaman. M.A, Wahyuni. S, Sabri. M. 2017. Pengaruh Pemberian Kombinasi Pakan Fermentasi dengan Multi Enzim dan Vitamin E dalam Ransum terhadap Peningkatan Kualitas Semen Ayam Arab. Jurnal Agripet. Vol.17. No.1.

[14] Ervandi. M, Ardiansya. W, Prahara. S. 2020. Kualitas dan Fertilitas Spermatozoa Sebagai Akibat Penjantan Berdeda. Jambura Journal of Animal Science. Vol.2. No. 2.

[15] Kusumawati. E.D, Krinaningsih. A.T.N, Walangara.A.U.K. 2020. Kualitas Spermatozoa Ayam Kampung Dan Ayam Arab Dengan Lama Simpan Yang Berbeda Pada Suhu Ruang. Jurnal Sains Peternakan. Vol. No. 8. ISSN 2579-4450.

[16] Muchlisin. Z.A, Sarah.P, Aldila. D.F. Eriani. K, Hasri. I, Batubara. A.S, Nur. F.M, Mustaqim. M, Muthmainnah. C.R, Abinawanto. A, Wilkes. M. 2020. Effect Of Dimethyl Sulfoxide (DMSO) And Egg Yolk On Sperm Motility, Fertility And Hatching Rates Of Depik Rasbora Tawarensis (Pisces:Cyprinidae) Eggs After Short-Term Cryopreservation. Aquaculture Research. DOI: 10.1111/are.14516.

[17] Putranto, H. D., Nurmeiliasari, Harferry, K. T. 2020. Studi Kualitas Semen Ayam Burgo. Buletin Peternakan Tropis, Vol 1(1):10-15.

[18] Kartasudjana, R. 2001. Teknik Inseminasi Buatan Pada Ternak. Modul Program Keahlian Budidaya ternak. Departemen Pendidikan Nasional Proyek Pengembangan Sistem Standar Pengelolaan SMK. Direktorat Pendidikan Menengah Kejuruan. Jakarta.

[19] Aisah, S., Isnaini, N., dan Wahyuningsih, S. 2017. Kualitas Semen Segar dan Recovery Rate Sapi Bali Pada Musim Yang Berbeda. Jurnal Ilmuilmu Peternakan Vol. 27 (1) : 63-79. 
The supplementation of Fermented Feed (Indegofera Sp and Eurycoma longifolia) Leaves on Arabic Chicken Semen

[20] Ramadhanty.D, Nugraha. A, Purnomo.N, Fausiah.A. 2021. Kualitas Makroskopis Semen Ayam Kampung Yang Diberi Ekstrak Kulit Buah Naga. Jurnal Ilmu Pertanian. Vol.6. No.1 :43-46.

[21] Harferry. K.T, Nurmeiliasari, Putranto. H.D. 2020. Studi Kualitas Ayam Burgo. Buletin Peternakan Tropis. Vol.1.(1) : 10-15. E-ISSN 2722-0788.

[22] Gethachew, T. 2016. A review article of artificial insemination in poultry. Veterinary Journal World Vet Journal, 26-35

[23] Silalahi, Marina .2019. Hubungan Pemanfaatan Tumbuhan Pasak Bumi (Eurycoma Longifolia Jack) Sebagai Obat Tradisional Dan Bioaktivitasnya. Jurnal Pendidikan Matematika Dan Ipa.Vol. 10 (2). Pp. 109-121. ISSN 25797530

[24] Toelihere, M. R. 1993. Inseminasi Buatan pada Ternak. Penerbit Angkasa, Bandung.

[25] Puteri. T.H, Enny. T.S, Yon. S.O. 2019. Pengaruh Indigofera sp. sebagai Suplemen Pengencer Semen terhadap Persentase Hidup dan Membran Plasma Utuh Spermatozoa Kambing Peranakan Etawa. Prosiding Seminar Nasional Fakultas Pertanian UNS. Vol. 3. No.1

[26] Bogar.B. CA, Tendean. L, Turalaki. G. LA. 2016. Pengaruh Pemberian Ekstrak Pasak Bumi (Eurycoma longifolia Jack) Terhadapat Kualitas Spermatozoa Tikus Wistar (Rattus norvegicus). Jurnal e-Biomedik. Vol.4.No.4.

[27] Fitriyah, F., Humaidah, N., \& Suryanto, D. (2019). Pengaruh Lama Penyimpanan Semen Dalam Pengencer Ringer's Lactat Yang Disimpan Pada Suhu $4^{\circ} \mathrm{c}$ Terhadap Kualitas Spermatozoa Ayam Magon. Jurnal Rekasatwa Peternakan, Vol. 1(1). 